\title{
Influence of land cover features on avian community and potential conservation priority areas for biodiversity at a Ramsar site in India
}

\author{
Souvik Barik', Goutam Kumar Saha ${ }^{1}$ and Subhendu Mazumdar ${ }^{2 *}$ (])
}

\begin{abstract}
Background: Wetlands provide diverse ecological services to sustain rich biodiversity, but they are recklessly exploited around the globe. East Kolkata Wetlands (EKW; Ramsar site No. 1208, 125 km²) was once very rich in faunal diversity that declined over the years due to various anthropogenic pressures. In such scenarios, effective management plans need to contemplate local and landscape level initiatives and prioritize areas for conservation. Studying the foraging guild structure and spatial patterns of relationship between bird and its environment provides important insight of ecological processes of avifauna. Thus, we carried out extensive surveys in 142 point count stations to explore the diversity and foraging guild structure of birds in EKW. We addressed two important questions that how bird diversity varied from the outer periphery of the city towards the wetlands and how bird diversity is influenced by land cover features at local and landscape level in wetland complex. The goal of this study was to prepare a spatial map of avian diversity and to find the conservation priority areas for birds in this internationally recognized wetland complex.

Results: We recorded 94 species of birds and the Shannon diversity index values ranged between 1.249 and 3.189. We found that the avian diversity increased with increasing distance from city periphery. Omnivores and insectivores were the dominant foraging guilds, followed by carnivores, granivores, frugivores and piscivores. Generalized Linear Models revealed that bird communities were positively influenced by areas of wetlands, dikes and banks, agricultural field and emergent vegetation, and negatively influenced by built-up area. In the projected spatial map of species diversity, $74.15 \mathrm{~km}^{2}$ area has high diversity. Finally, we identified $12.82 \mathrm{~km}^{2}$ of top $10 \%$ conservation priority areas.

Conclusions: Low bird diversity near city periphery is related to habitat degradation due to anthropogenic pressure. Dominance of omnivores and insectivores indicates a possible impact of urbanization in EKW. We suggest that a mix of agricultural field, wetland areas and emergent vegetation helps to sustain a greater avian community. Besides, protection of conservation priority areas, restoration of the degraded habitats and reduction of threats (particularly in the north-eastern parts of EKW near the city periphery) will ensure the conservation of avifauna, and also the overall biodiversity of EKW.
\end{abstract}

Keywords: Bird diversity, Spatial mapping, FRAGSTATS, ZONATION, Wetland management, East Kolkata Wetlands

\footnotetext{
*Correspondence: subhendumazumdar@gmail.com

2 Department of Zoology, Shibpur Dinobundhoo Institution (College),

Shibpur, Howrah, India

Full list of author information is available at the end of the article
}

\section{Background}

Wetlands are fragile ecosystems (Fraser and Keddy 2005) that provide several vital ecological services and play very important role in sustaining biodiversity (Leibowitz 2003; Millennium Ecosystem Assessment [MEA] 2005). However, wetlands are diminishing worldwide (Millennium Ecosystem Assessment [MEA] 2005; Mazumdar 
and Saha 2016). East Kolkata Wetlands (henceforth EKW) is a unique wetland ecosystem (Parihar et al. 2013) and is recognized as a 'Wetland of International Importance' (Ramsar Convention 2002). It is unique being the largest resource-recycling system of the world, where large volumes of wastewaters of Kolkata metropolis are treated (Mukherjee and Chakraborty 2016). The wetland was once very rich in floral and faunal diversity, which declined over the years due to rapid population growth, unplanned urbanization and encroachment of certain parts of wetlands due to flourishing real estate sector (Bhattacharyya et al. 2008; Parihar et al. 2013; Ghosh et al. 2018). Studies carried out in EKW had earlier recorded 271 avian species, but, the shrinkage and transformation of EKW and degradation of the habitat quality due to various anthropogenic activities (Ghosh et al. 2018) have led to the local disappearance of 109 species, mostly the aquatic birds, from the wetland complex (EKWMA 2010). This demands a conservation oriented management plan for this unique ecosystem to ensure the continued existence of existing biodiversity (Parihar et al. 2013). Such conservation planning needs comprehensive understanding of the relationships of the organisms with their respective environment (O'Neil and Carey 1986).

Birds are sensitive to environmental changes and are therefore, frequently used as indicators for various ecological studies and often considered as good surrogate of biodiversity in a particular area (Alexandrino et al. 2016). Besides, local and landscape level characteristics of wetlands often influence avian ecological processes such as habitat dependencies, foraging, distribution (Bennett et al. 2009; Douglas et al. 2010; Lee and Carroll 2014). Wetland features like water area, dikes and banks and adjacent vegetation cover, as well as the crop fields often influence wetland-dependent bird communities (Sundar and Kittur 2013; Barik et al. 2021a, b, c). Bird conservation plans need to consider the influence of various environmental features at local, as well as landscape level spatial extents on the avian communities (Lee and Carroll 2014). Earlier studies on the birds of EKW mostly provided only the list of avian species encountered (Ghosh and Sen 1987; Ghosh 1990; Bhattacharyya et al. 2008; EKWMA 2010; Saha et al. 2014). However, studies on the relationship between avian diversity and wetland habitat features at local and landscape level spatial scales are less and are particularly non-existing in EKW.

In the present study, first we analysed the species richness and abundance of birds belonging to different foraging guilds, which is unexplored in EKW. Studies on foraging guild structure provide a clear understanding of avian community structure and adaptation of birds towards changing physical environments (Snep et al.
2015; Sohail and Sharma 2020). Secondly, we hypothesized that the bird diversity in EKW increased with increasing distance from Kolkata Municipal Corporation (henceforth, KMC) boundary towards the wetland. Next, we addressed an important question of how bird diversity is influenced by land cover features at local and landscape level spatial extents in wetland complex. Also, wetland authorities are interested to know the areas with rich avian diversity to prioritize areas for conservation initiatives. In any landscape, areas and land cover features that support high bird diversity need to be prioritized for conservation and management (Moilanen et al. 2011). Such conjointly designed conservation and management strategy will ensure the long-term retention of bird diversity of EKW (Moilanen et al. 2011; Giosa et al. 2018). Therefore, our aim was to find the high bird diversity areas, for this purpose we projected a spatial map of bird diversity. Finally, by using the spatial map of bird diversity and important land cover features, we identified the conservation priority areas for birds in an internationally recognized wetland complex for future conservation, which is undergoing land cover changes and habitat degradation over the years.

\section{Materials and methods \\ Study area}

The present study was carried out in EKW, which is situated on the eastern part of Kolkata, West Bengal India (Fig. 1a, b; latitude: $22^{\circ} 25^{\prime}-22^{\circ} 40^{\prime} \mathrm{N}$; longitude: $88^{\circ} 22^{\prime}-$ $88^{\circ} 55^{\prime} \mathrm{E}$, altitude: $1-5 \mathrm{~m}$ asl; area: $\sim 125 \mathrm{~km}^{2}$ ). This is a wetland of international importance delivering environmental benefits worth $\$ 38.54$ million and was declared as Ramsar site in November 2002 (Bhattacharyya et al. 2008). The land use of EKW primarily includes sewage water channels, vast stretches of sewage-fed aquaculture ponds, shallow marshlands, dikes, agricultural fields, residential areas and dumping grounds. The depth of most of the wetlands ranges between 0.7 and $3 \mathrm{~m}$. Floating macrophytes are often present near the banks of the aquaculture ponds, while the areas not used for pisciculture harbour emergent macrophytes along with other wetland-associated vegetation (Bhattacharyya et al. 2008).

\section{Bird surveys}

Surveys conducted at a series of point locations (point counts) are a common tool for ecological monitoring, particularly for birds (Bibby et al. 2000). Initially $1161 \times 1 \mathrm{~km}^{2}$ grid layer was overlaid on the surface falling inside the boundary of EKW (Fig. 1b), then 71 grids were selected (through random number generation and based on accessibility). Two points were randomly placed in each of these 71 selected grids keeping a minimum 


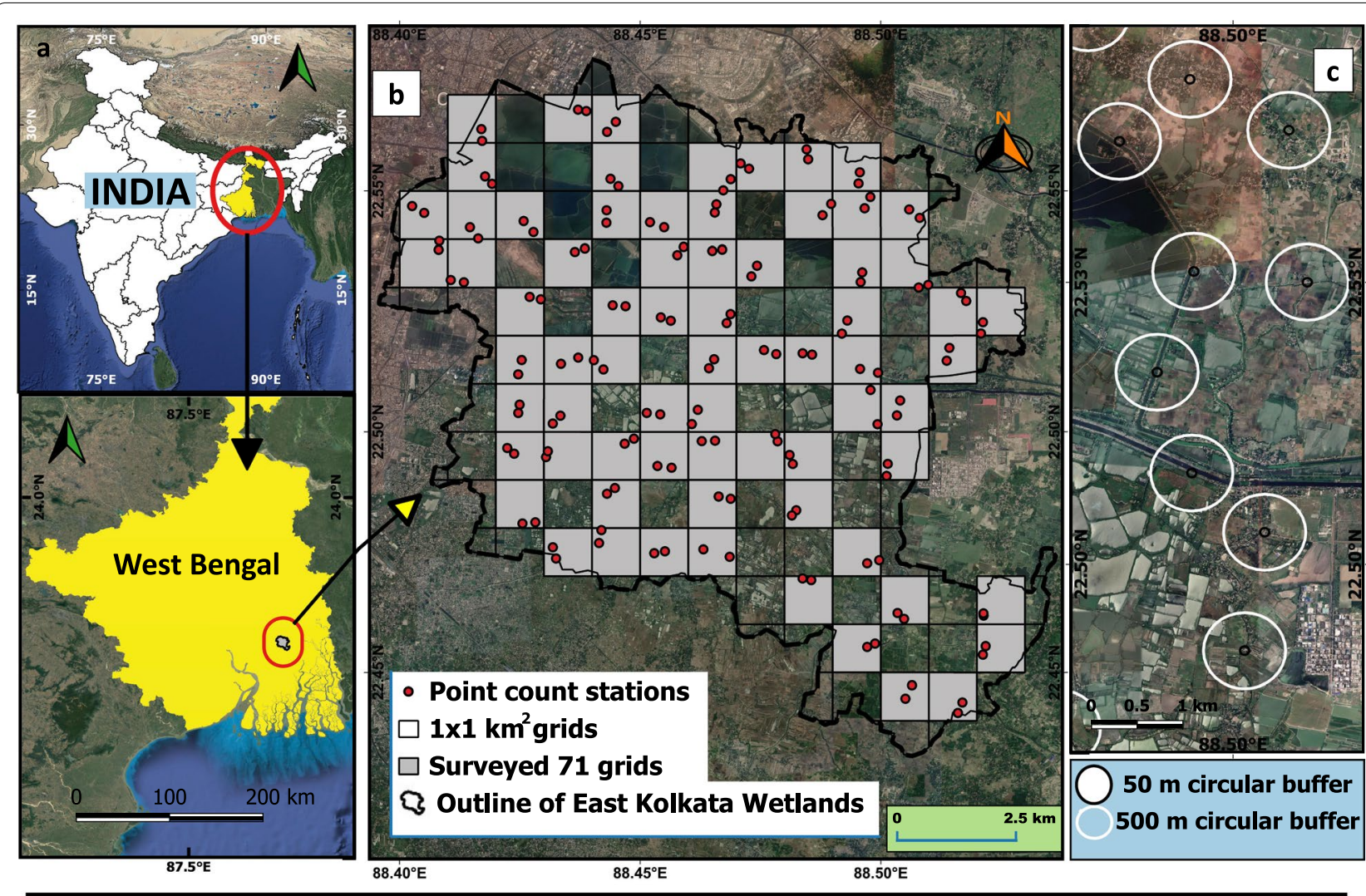

Fig. 1 a Location of the study area in West Bengal, India. b Map of study area showing surveyed grids and point count stations, in EKW. c Local $(50 \mathrm{~m})$ and landscape $(500 \mathrm{~m})$ scale circular buffer

gap of $250 \mathrm{~m}$ between two adjacent points (Fig. 1b). Then, surveys were carried out in each of the 142 bird count stations ( 71 grids $\times 2$ stations per grid) four times between June 2019 and March 2020. Point counts were carried out during morning (between 06:00 and 10:00 when the birds were most active) wherein the individual birds belonging to different species (through visual observation or listening to their calls) were recorded for 10 min (Bibby et al. 2000).

\section{Bird species and functional classification}

Birds were identified and their dispersal status (resident or migratory) was noted from standard field guides (Ali et al. 1987; Grimmett et al. 2013). Thereafter, we calculated Shannon diversity indices of avifauna $\left(H=-\sum p_{i} \ln \right.$ $p_{i}$, where $p_{i}=$ proportion of individuals that belong to species $i$, Shannon and Weaver 1949). 'Water birds' were categorized as per wetland bird list provided by Wetland International (http://wpe.wetlands.org/Iwhatrwb) and the remaining birds are categorized as 'terrestrial birds'. We grouped the avian species into six foraging guilds such as omnivorous, insectivorous, carnivorous, piscivorous, granivorous and frugivorous following Sohail and
Sharma (2020). The diets of the birds were also determined based on our field observation as well as referring to HBW Alive (2021) (Additional file 1).

\section{Local and landscape-scale variables selection}

We considered land cover types within $50 \mathrm{~m}$ and $500 \mathrm{~m}$ circular buffers around the point count stations as localscale and landscape-scale variables, respectively (Table 1; Fig. 1c; Bibby et al. 2000; Lee and Carroll 2014; Litteral and Shochat 2017). Local scale land cover variables were assessed using high resolution Google Earth satellite image ( $1 \mathrm{~m}$ spatial resolution), while landscape-scale variables were measured using Sentinel-2 satellite images (Barik et al. 2021a, b, c; Lamy et al. 2016). The Sentinel-2 satellite images with minimum cloud cover (15 November 2020) downloaded from USGS Earth Explorer (https:// earthexplorer.usgs.gov) and prepared the present land cover map of the study area (with 10 m resolution, Fig. 2) in QGIS through supervised 'minimum distance classification' (Abburu and Golla 2015) using Semi-automatic Classification Plugin (Congedo 2014, 2016). We prepared an error 'matrix' by using a total of 9160 ground truth points for accuracy estimation of the land cover layer of 
Table 1 Description of local and landscape-scale land cover classes within study area

\begin{tabular}{lll}
\hline Land use land cover classes & Description \\
\hline Local scale & Water area & Areas with standing water cover \\
& Dikes and banks & Areas of embankment for controlling or holding the waters of the bheri and ponds \\
Agricultural field & Arable land for different crops, vegetables \\
& Tree cover & Area of the tree canopy area when viewed from above \\
Open ground & Areas of fallow lands play grounds and barren lands \\
Built-up area & Areas of house, buildings, etc \\
Wetlands & Areas of bheri, ponds, and lakes \\
Dikes and banks & Areas of embankment for controlling or holding the waters of the bheri and ponds \\
& Emergent vegetation & Areas where marsh, uncultivated shrubs and bushes were seen to grow \\
& Agricultural field & Arable land with standing crops, vegetables \\
Fallow lands & Arable land without standing crops, vegetables \\
Tree cover & Area of the tree canopy area when viewed from above \\
Human-settlements & Areas of urban and rural settlements \\
Barren lands & Areas of without any vegetation cover \\
\hline
\end{tabular}

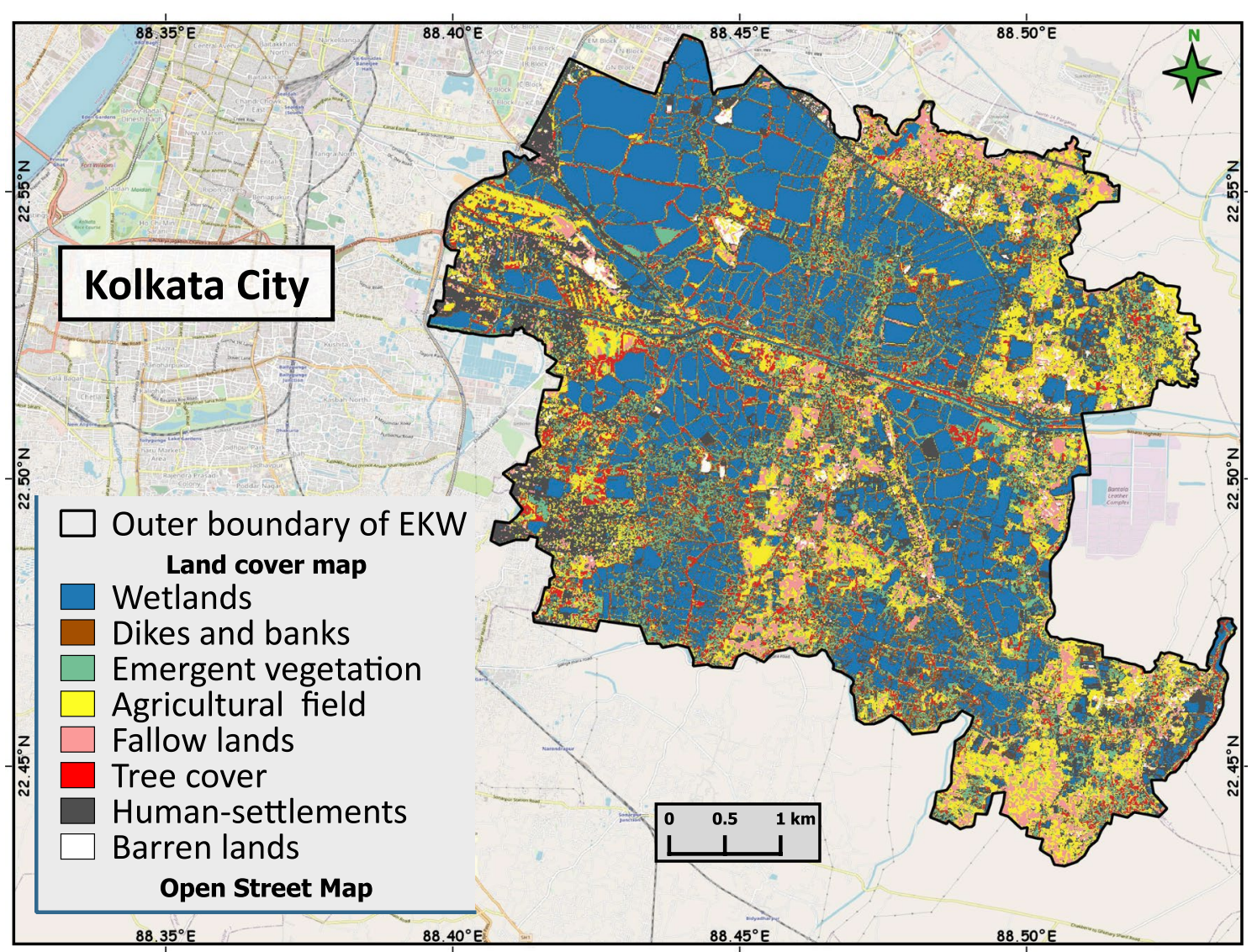

Fig. 2 Land cover map of EKW

the study area (Campbell 1996), which revealed 96.56\% overall accuracy ( $>85 \%$ considered as standard limit by Anderson et al. 1976) and kappa coefficient 0.96 (Table 2) indicating very good to excellent accuracy (Cohen 1960; Landis and Koch 1977). We used FRAGSTATS software (ver. 4, McGarigal 2015) derived class area metrics (i.e. the 
sum of the areas of all patches belonging to the respective land cover class) to quantify the areas of each land cover class within $500 \mathrm{~m}$ circular buffer. However, the samples need to be non-overlapping, spatially independent landscapes (Pasher et al. 2013). Hence, the overlapping sampling sites were removed prior to landscape level analyses (Koper and Schmiegelow 2006). So, we carried out the landscape level analyses in 51 spatially non-overlapping landscape of $500 \mathrm{~m}$ circular buffer, where the observed mean distance (obtained from 'nearest neighbour analysis' in QGIS) between nearest neighbour is $1.25 \mathrm{~km}$ and nearest neighbour index is 1.44 with high positive significant $z$ score $(z=6.05, p<0.05)$. So, our landscape level sampling plots are spatially well-dispersed throughout the study area (Jude et al. 2018). The species diversity data obtained from the complete dataset of 142 study points (species diversity Mean $\pm \mathrm{SE}=2.262 \pm 0.132$ ) and data from 51 spatially non-overlapping study points (species diversity Mean $\pm \mathrm{SE}=2.277 \pm 0.023)$ did not show any significant variation (Kruskal-Wallis tests: $H=181.81, d f=182$, $p>0.05$ ), which indicates sampling adequacy (Kaliyadan and Kulkarni 2019).

\section{Data analysis}

Species richness and abundance data followed nonnormal distribution (Shapiro-Wilk's tests: $W_{\text {species rich- }}$ ${ }_{\text {ness }}=0.929, d f=567, p<0.05 ; W_{\text {species abundance }}=0.851$, $d f=567, p<0.05)$. Hence, non-parametric Kruskal-Wallis tests were applied to compare species richness and abundance between terrestrial and water birds, as well as between different foraging guilds. We prepared scatter plots to illustrate the variation in species richness and abundance of different species of avifauna belonging to each of the six different foraging guilds (Fig. 3). Further, we performed Agglomerative Hierarchical Cluster (AHC) analysis using Jaccard's similarity coefficient (Krebs 1989; Manly 1994) and constructed a dendrogram using unweighted pair-group average (UPGA; Hammer et al. 2001) in 'BinMat' package (van Steenderen 2020) of $\mathrm{R}$ to show similarities in foraging guild structure among observed bird families in EKW (Fig. 4).

Thereafter, we measured the linear distance of each point count stations in EKW from the KMC boundary in QGIS (ver. 3.6) and calculated the Shannon indices of bird diversity at each point count station in PAST (ver. 3.06) software (Hammer et al. 2001). ShapiroWilk's tests revealed that the species diversity data at local $(W=0.995 ; d f=567, p>0.05)$ and landscape scale ( $W=0.994, d f=203, p>0.05$ ) were normally distributed, thus we performed Generalized linear models (henceforth, GLM) with Gaussian error distribution and identity link (Zuur et al. 2009) to show how bird diversity of EKW influenced by distance and land cover variables at local and landscape level spatial extents using 'MASS' package (Ripley 2011). We created three separate models for each spatial scale. In the first model, we used only land cover features as explanatory variable. In the second model, we used distance to KMC boundary as explanatory variable. Third model was built by using land cover and distance variables jointly as explanatory variables. The multicollinearity in GLM was identified by calculating a variance inflation factor (VIF) for each variable in created models (Smith and Warren 2019) using 'car' (Fox and Weisberg 2019) and 'performance' package (Lüdecke

Table 2 Land cover accuracy assessment through error 'matrix'

\begin{tabular}{|c|c|c|c|c|c|c|c|c|c|}
\hline & Wetlands & $\begin{array}{l}\text { Emergent } \\
\text { vegetation }\end{array}$ & Agricultural field & Tree cover & $\begin{array}{l}\text { Human- } \\
\text { settlements }\end{array}$ & $\begin{array}{l}\text { Barren } \\
\text { lands }\end{array}$ & Dikes and banks & Fallow lands & Total \\
\hline Wetlands & 8318 & 0 & 0 & 0 & 0 & 0 & 0 & 0 & 8318 \\
\hline $\begin{array}{l}\text { Emergent vegeta- } \\
\text { tion }\end{array}$ & 0 & 273 & 2 & 1 & 2 & 0 & 0 & 0 & 278 \\
\hline Agricultural field & 0 & 0 & 140 & 3 & 8 & 0 & 0 & 1 & 152 \\
\hline Tree cover & 0 & 0 & 0 & 6 & 0 & 0 & 0 & 0 & 6 \\
\hline $\begin{array}{l}\text { Human-settle- } \\
\text { ments }\end{array}$ & 0 & 0 & 4 & 0 & 289 & 2 & 2 & 0 & 297 \\
\hline Barren lands & 0 & 0 & 0 & 0 & 0 & 42 & 0 & 0 & 42 \\
\hline Dikes and banks & 0 & 0 & 0 & 0 & 0 & 0 & 10 & 0 & 10 \\
\hline Fallow lands & 0 & 0 & 1 & 0 & 4 & 0 & 0 & 52 & 57 \\
\hline Total & 8318 & 273 & 147 & 10 & 303 & 44 & 12 & 53 & 9160 \\
\hline $\begin{array}{l}\text { Producer accuracy } \\
(\%)\end{array}$ & 100 & 100 & 96.43 & 92.19 & 94.45 & 93.37 & 96.42 & 98.52 & \\
\hline User accuracy (\%) & 100 & 98.20 & 92.11 & 100 & 97.31 & 100 & 100 & 91.23 & \\
\hline Standard error & 0 & 0.0009 & 0.0051 & 0.0023 & 0.0057 & 0.0015 & 0.0015 & 0.0038 & \\
\hline
\end{tabular}

Overall accuracy $=96.56 \%$, Kappa coefficient $=0.96$ 
Table 3 Principal components (PC) loadings (correlation coefficients) obtained from principal component analysis (with varimax rotation) on landscape-scale land cover variables. (PC1 is correlated to wetland area, PC2 is correlated to emergent vegetation area, and PC3 is correlated to agricultural field area)

\begin{tabular}{llll}
\hline \multirow{2}{*}{$\begin{array}{l}\text { Landscape-scale land cover } \\
\text { variables }\end{array}$} & \multicolumn{3}{l}{ Principal components } \\
\cline { 2 - 4 } & PC1 & PC2 & PC3 \\
\hline Wetlands & $\mathbf{0 . 5 1 *}$ & -0.25 & 0.30 \\
Emergent vegetation & 0.2 & $\mathbf{0 . 5 4}$ & -0.26 \\
Agricultural field & -0.09 & 0.13 & $\mathbf{0 . 7 2 *}$ \\
Tree cover & -0.35 & 0.37 & 0.45 \\
Human habitation & 0.3 & 0.39 & -0.19 \\
Barren lands & 0.2 & -0.54 & 0.06 \\
Dikes and banks & -0.63 & -0.21 & -0.3 \\
Fallow lands & 0.2 & -0.1 & -0.3 \\
Variance explained & $40 \%$ & $29 \%$ & $14 \%$ \\
Cumulative variance & $40 \%$ & $69 \%$ & $83 \%$ \\
\hline
\end{tabular}

Bold fonts with '*' marked are the highest component loadings and values $>0.5$ are used to explain the PC

et al. 2019) in R. We have calculated the generalized variance inflation factor (GVIF) for predictor variables at local scale (binary categorical variables $(n=7, d f>1)$ following Fox and Monette (1992) and found GVIF $<1.1$. This clearly indicates low inter-correlation between the predictor variables. On the other hand, landscape-scale land cover variables are showing high multicollinearity (VIF > 10) in the model (Zuur et al. 2007; Smith and Warren 2019). To solve this multicollinearity issue, principal component analysis (PCA) was performed on landscapescale land cover variables using 'princomp' function (Gwelo 2019). We retained three principal components (henceforth, PC) which collectively explained $>70 \%$ of the cumulative variance (considered as standard limit by Jolliffe 2002, Table 3). In our study, PC1, PC2 and PC3 explained 40, 29, 14\% of variance, respectively, and thus collectively explained $83 \%$ of cumulative variance (Table 3). We used varimax rotation, which is the most common rotation method to simplify interpretation of principal components (Abdi and Williams 2010). Variables with correlation coefficient or loading values $<0.5$ were not considered for interpretation of PCs following Lee and Carroll (2014). We found that PC1, PC2, and PC3 are positively correlated with areas of wetlands, emergent vegetation, agricultural field area, respectively (Table 3). Scores of the principal components were then used as explanatory variables in the subsequent GLMs at landscape scale (Graham 2003). Finally, we ranked all the models based on their respective second-order Akaike's information criterion (henceforth, AICc) values using
"AICcmodavg" package (Mazerolle 2020) and the models with lowest AICc values were considered as the best model (Table 4). To find out the importance of explanatory variables in the best model, we standardized the estimate values following Silva et al. (2015) using "reghelper" package (Hughes et al. 2021) in R (Table 4, Fig. 5). All the statistical test were carried out in R studio (ver. 1.3.1073) and Past (ver. 4.03; Hammer et al. 2001).

Next, we plotted a spatial map of bird diversity over the surface of EKW (Fig. 6), through Inverse Distance Weighting function of QGIS (with default power value) which is commonly used in avian research (Li and Heap 2011; Gutiérrez-Tapia et al. 2018; Touhami et al. 2019). We used Shannon diversity index values of each surveyed locations to create the spatial map of bird diversity following Izaguirre and Ramírez-Alán (2018) and Morelli et al. (2018). One reasonable measure of efficiency of interpolated map is the root mean square error (RMSE) and the RMSE value of interpolated spatial map of diversity in our study was 0.0002 , which indicates high accuracy (Ouabo et al. 2020). To develop a spatial conservation prioritization model we used the Zonation software (v. 3.1.0; Lehtomäki and Moilanen 2013). Zonation prioritizes the areas based on input layers (grid cells), which are simultaneously processed to assign a hierarchical rank to each cells. The cells with least values within the study area are discarded at the beginning and the most valuable cells are retained till the end. This process of progressive removal of cells may identify most important areas for conservation (Lehtomäki and Moilanen 2013). At present rate of urban expansion and wetland transformation in EKW (Ghosh et al. 2018) we also need to manage those land covers, which have positive influence on bird communities of EKW. Following Lehtomäki and Moilanen (2013) and Di Minin et al. (2014), we used the spatial map of bird diversity and the land cover layers (showing significant positive influence on avian diversity) as input layers in Zonation software. Equal weight was given to each of them and used the warp factor value of 50 (Moilanen et al. 2011; Di Minin et al. 2014). We then used the Core-Area Zonation function and identified the high-quality localities in the final output map (Lehtomäki and Moilanen 2013). Thus, top 10\% conservation priority areas were identified in the Zonation output map of EKW (Fig. 7). We finally used a 50-m buffer around the top $10 \%$ conservation priority area, which may minimize the effects of anthropogenic disturbances in the conservation priority area (McElfish et al. 2008). 


\section{Results}

\section{Bird diversity and correlation with distance to outer} periphery of KMC area

During the present study, we recorded a total of 27,623 individuals of birds belonging to 94 species, of which 26 species (27.66\%) were water birds and 68 species were terrestrial birds (72.34\%) and the species richness and abundance of terrestrial and water birds varied significantly (Kruskal-Wallis tests: $H_{\text {richness }}=834.4, d f=1$, $p<0.05 ; H_{\text {abundance }}=725.4, d f=1, p<0.05$; Dunn post hoc tests: $z_{\text {richness }}=14.57, z_{\text {abundance }}=14.05$, Bonferroni corrected $p$ value $<0.05)$. All these 94 avian species fall under 14 orders and 41 families. Passeriformes, with 38 species of birds, was found to be the most diverse avian order in EKW. We found 13 species of winter visitor and remaining species were resident. Twenty one species having globally declining population trend were recorded during the present study, of which two species were near-threatened (Black-headed ibis Threskiornis melanocephalus and Alexandrine parakeet Psittacula eupatria), while the remaining species fall under the least concern category of IUCN red list (del Hoyo et al. 2014). The Shannon diversity indices values ranged between 1.249 to 3.189 and the obtained mean $\pm S E$ values of Shannon diversity indices were $2.262 \pm 0.013$.

\section{Foraging guild structure and UPGA cluster analysis}

The abundance (Kruskal-Wallis test: $H=2118.3, d f=5$, $p<0.05)$ and richness $(H=2190.1, d f=5, p<0.05)$ of avian species significantly varied between foraging guilds. Omnivores and insectivores were highest (31 species in each, 32.98\%), followed by carnivores (19 species, 20.21\%), granivores (6 species, 6.38\%), frugivores (5 species, $5.32 \%$ ) and piscivores (2 species, $2.13 \%$ ). In the scatter plots, we observed dissimilar patterns in the abundance of birds belonging to different foraging guilds. The abundance of avian species belonging to omnivorous guild was highest, followed by carnivorous, insectivorous, granivorous, piscivorous and frugivorous (Fig. 3). AHC analysis revealed that the avian families recorded in the present study fall under eight distinct groups (Fig. 4), namely $I=$ frugivorous (two families), $\mathrm{II}=$ piscivorous (only one family), $\mathrm{III}=$ granivorous (two families), $V=$ carnivorous (five families), $V I=$ insectivorous (13 families), VII = omnivores (14 families). Group IV and VIII shared more than one food resources and thus were categorized as carnivorous/insectivorous (one species) and omnivorous/insectivorous (three families), respectively.
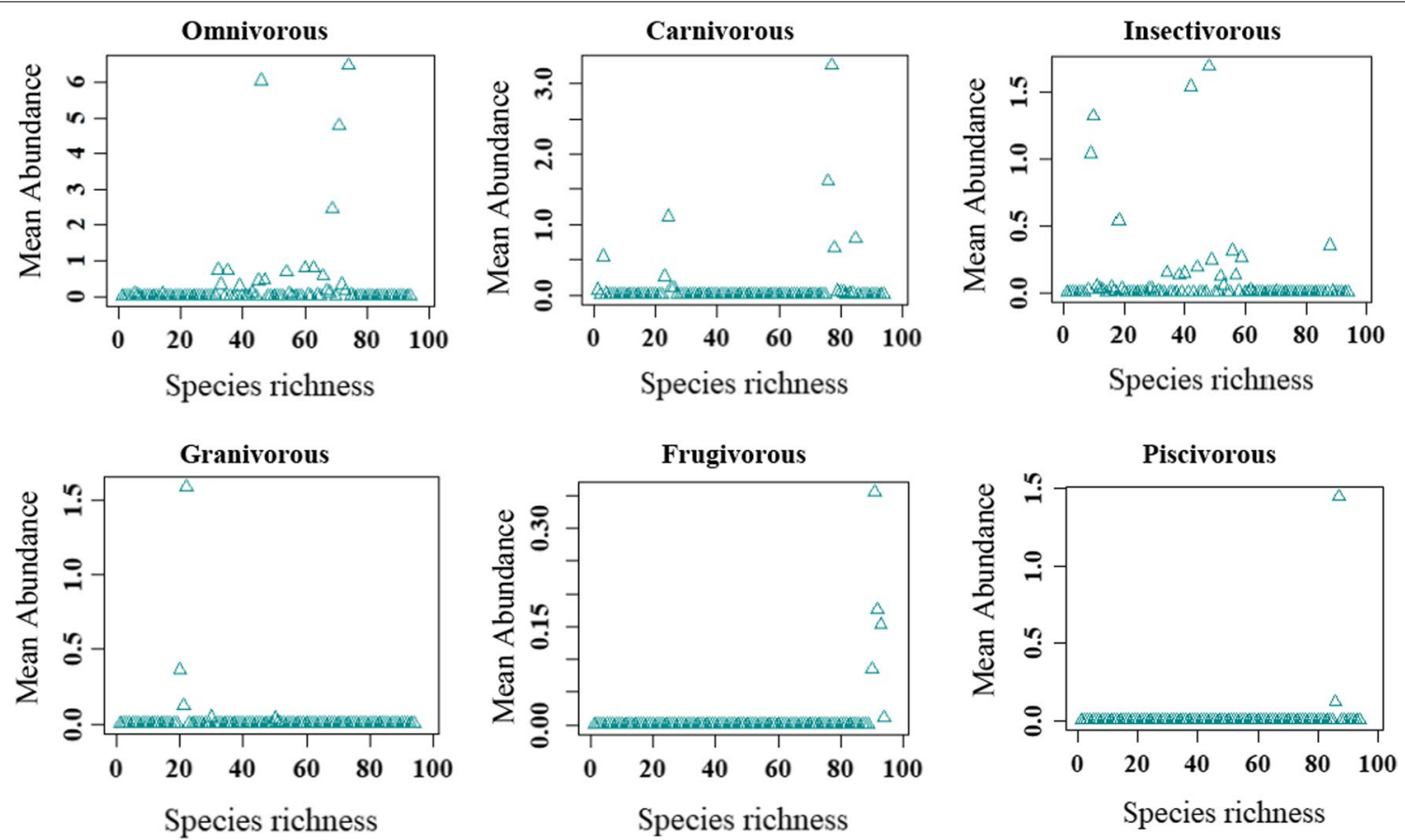

Fig. 3 The mean abundance of bird species belonging to each of the avian foraging guilds of EKW. (The vertical axes represent the mean abundance of birds in respective foraging guilds, and horizontal axes represent the species richness.) 


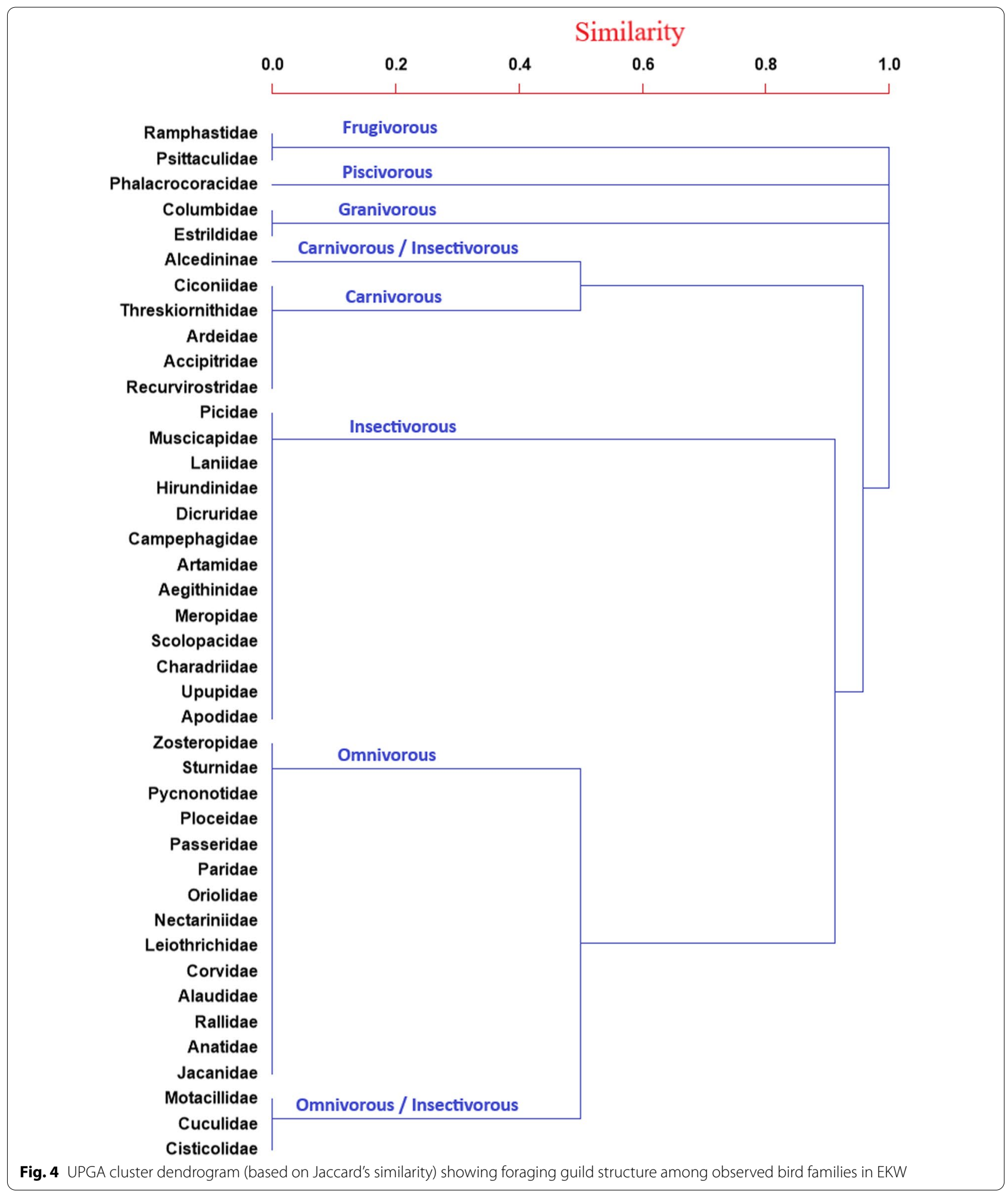


Table 4 Generalized linear models of bird diversity in relation to local and landscape-scale land cover variables and distance to KMC boundary variable

\begin{tabular}{|c|c|c|c|c|}
\hline Spatial scales & Models & Variables ( $\beta$ estimate \pm SE) & $t$ values & AICc values \\
\hline \multirow[t]{3}{*}{ Local scale } & $\begin{array}{l}\text { 1. glm(Bird diversity } \sim \mathrm{WA}+\mathrm{DB}+\mathrm{AF}+ \\
\mathrm{TC}+\mathrm{OG}+\mathrm{BA})\end{array}$ & $\begin{array}{l}W A=-0.01 \pm 0.016 \\
\mathrm{DB}=0.04 \pm 0.016 \\
\mathrm{AF}=0.011 \pm 0.013 \\
\mathrm{TC}=0.006 \pm 0.013 \\
\mathrm{OG}=0.02 \pm 0.013 \\
\mathbf{B A}=-0.052 \pm 0.014\end{array}$ & $\begin{array}{l}W A=-0.627 \\
D B=2.543 \\
A F=0.862 \\
T C=0.471 \\
O G=1.509 \\
B A=-3.802\end{array}$ & 288.85 \\
\hline & 2. glm(Bird diversity $\sim \mathrm{DKB})$ & $\mathrm{DKB}=0.075 \pm 0.013$ & $\mathrm{DKB}=5.848$ & 272.82 \\
\hline & $\begin{array}{l}\text { 3. glm(Bird diversity } \sim \mathrm{WA}+\mathrm{DB}+\mathrm{AF}+ \\
\mathrm{TC}+\mathrm{OG}+\mathrm{BA}+\mathrm{DKB})\end{array}$ & $\begin{array}{l}W A=-0.001 \pm 0.015 \\
D B=0.031 \pm 0.016 \\
A F=-0.011 \pm 0.014 \\
T C=0.007 \pm 0.014 \\
O G=0.009 \pm 0.013 \\
\mathbf{B A}=-0.046 \pm 0.013 \\
\mathbf{D K B}=0.072 \pm 0.014\end{array}$ & $\begin{array}{l}W A=-0.046 \\
D B=1.975 \\
A F=-0.823 \\
T C=0.521 \\
O G=0.709 \\
B A=-3.417 \\
D K B=5.169\end{array}$ & 264.45 \\
\hline \multirow[t]{3}{*}{ Landscape scale } & 1. $g \operatorname{lm}$ (Bird diversity $\sim P C 1+P C 2+P C 3)$ & $\begin{array}{l}P C 1=0.069 \pm 0.022 \\
P C 2=0.017 \pm 0.022 \\
P C 3=0.083 \pm 0.022\end{array}$ & $\begin{array}{l}P C 1=3.066 \\
P C 2=0.779 \\
P C 3=3.699\end{array}$ & 119.02 \\
\hline & 2. $\mathrm{glm}$ (Bird diversity DKB) & $\mathbf{D K B}=0.095 \pm 0.023$ & $\mathrm{DKB}=4.199$ & 120.6 \\
\hline & $\begin{array}{l}\text { 3. } g \operatorname{lm}(\text { Bird diversity } \sim P C 1+P C 2+P C 3 \\
+D K B)\end{array}$ & $\begin{array}{l}\mathbf{P C} 1=0.119 \pm 0.022 \\
\mathbf{P C 2}=0.045 \pm 0.021 \\
\mathbf{P C}=0.077 \pm 0.020 \\
\mathbf{D K B}=0.142 \pm 0.022\end{array}$ & $\begin{array}{l}P C 1=5.406 \\
P C 2=2.148 \\
P C 3=3.759 \\
D K B=6.351\end{array}$ & 83.49 \\
\hline
\end{tabular}

WA water area, $D B$ dikes and banks, $A F$ agricultural field, $T C$ tree cover, $O G$ open ground, $B A$ built-up area, $D K B$ distance to KMC boundary, $P C$ principal component; bold fonts of variables indicate $p<0.05$; The lowest AICc values indicate the best model

\section{Local and landscape-scale bird response}

The lowest AICc value revealed that the conjoint model containing land cover and distance to KMC boundary as explanatory variables were the best models both at local and landscape scales (Table 4). Relative importance of explanatory variables of the best GLM models is depicted in Fig. 5. Amongst the local-scale land cover variables, species diversity was positively influenced by presence of dikes and banks $(B=0.031)$ and negatively influenced by presence of built-up area $(B=-0.046)$ (Table 4, Fig. 5).

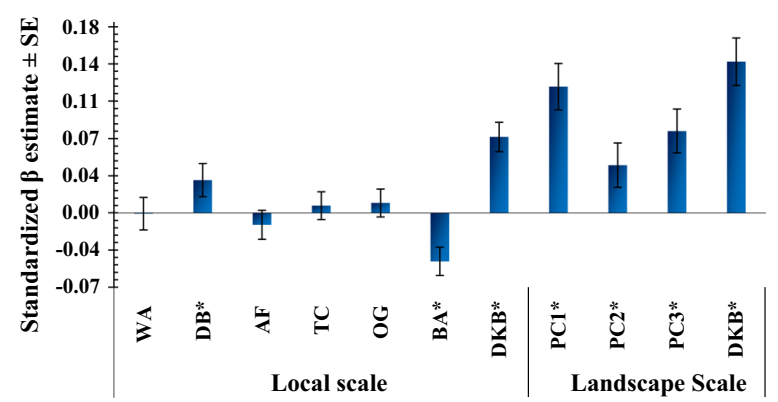

Fig. 5 Relative importance of variables (standardized $\beta$ estimates) in the best GLM models at local and landscape scale (WA water area, $D B$ dikes and banks, AF agricultural field, TC tree cover, OG open ground, $B A$ built-up area, $D K B$ distance to KMC boundary, $P C$ principal component, SE standard error)
At landscape scale, GLM further revealed that PC1 (correlated to wetlands area, $B=0.119$ ), $\mathrm{PC} 2$ (correlated to emergent vegetation area, $B=0.045)$ and PC3 (correlated to agricultural field areas, $B=0.077$ ) positively influenced the species diversity (Table 4, Fig. 5). At both scales, we found that the bird diversity of EKW increased with increasing distance from KMC boundary (local scale: $B=0.072$, landscape scale: $B=0.142$ ) (Fig. 5).

\section{Spatial map of species diversity and top conservation priority areas}

We classified the spatial map of diversity into two categories (i) areas with Shannon diversity index $<2.262$ and (ii) areas with Shannon diversity index $>2.262$. Thus, we identified $74.15 \mathrm{~km}^{2}$ area with higher and $54.09 \mathrm{~km}^{2}$ area with lower than mean species diversity in EKW (Fig. 6) and the land cover types falling under each of these classes are presented in Table 5. Based on relative importance of land cover variables (Fig. 5), we selected land cover layers of wetlands, dikes and banks, emergent vegetation, agricultural field, as well as, the spatial map of avian diversity as input layers for Zonation and identified $12.82 \mathrm{~km}^{2}$ of top $10 \%$ conservation priority areas in EKW along with their respective land cover types (Table 5; Fig. 7). 


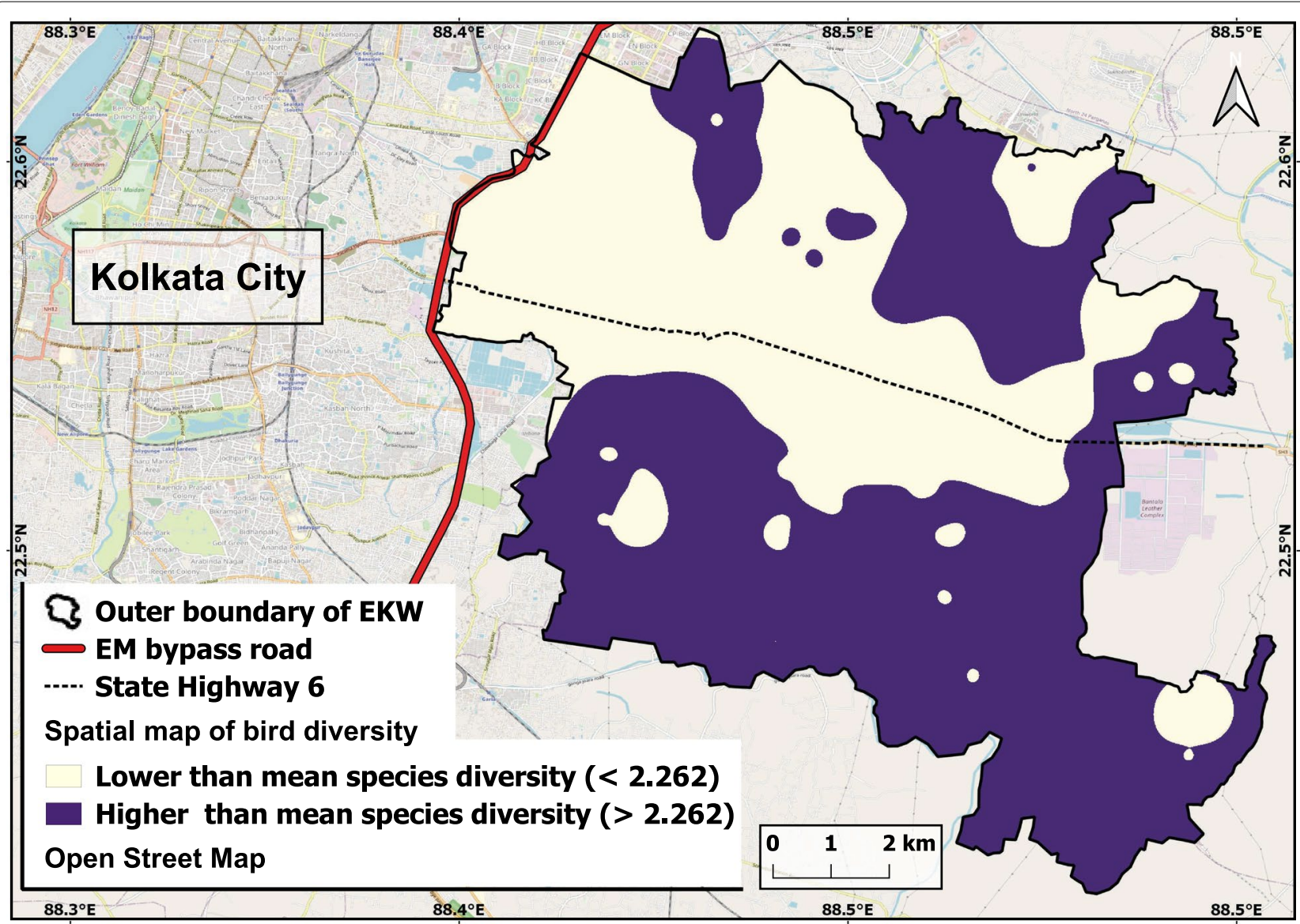

Fig. 6 Spatial map of bird diversity showing areas of higher and lower than mean bird diversity in EKW

\section{Discussion}

Increasing wetland transformation in EKW reduces wetland cover (Ghosh et al. 2018), which is the major cause of decreasing water bird populations (Sica et al. 2020). Hence, despite EKW being a wetland, we found that the species richness and abundance of terrestrial birds were highest. On the other hand, urban expansion is known to adversely influence the avian communities living in the adjoining natural environments (Blair and Johnson 2008). We found that the species richness belonging to order Passeriformes was highest, which is also a possible indication of urbanization in EKW (La Sorte et al. 2018). The species richness and abundance varied across six foraging guilds (Fig. 3). Omnivores and insectivores were found to be the major foraging guild, followed by carnivores, granivores, frugivores and piscivores in our study area (Figs. 3 and 4). Urban expansion favours insectivorous birds, and the omnivores with wider dietary spectrum also thrive better in human-dominated landscapes (Sohail and Sharma 2020; Kurucz et al. 2021). Highest species richness of the omnivores and insectivores in our study area also indicates a possible impact of urbanization in this wetland complex. On the other hand, frugivores require fruit-bearing plants and few number of frugivores is an indication of increased habitat degradation (Sohail and Sharma 2020). Also unexpectedly, despite EKW being a wetland complex, we found only two species of piscivores. Piscivores are reported to damage fish stocks (Harris et al. 2008). In EKW the fishermen often cover the commercial fishponds with fine fishnets, denying the access of the piscivores. Such denial of their access to preferred resource is disadvantageous for birds belonging to such specialist foraging guild (Burin et al. 2016).

In agreement to our second hypothesis, we found that multiple land cover features at local and landscape scale influence the bird species diversity (Table 4, Fig. 5). Among the land cover features, agricultural field positively influence the bird diversity at landscape scale (Table 4, Fig. 5). The agricultural fields serve as important nesting and foraging habitat for several bird species (Wilcoxen et al. 2018). The high density 


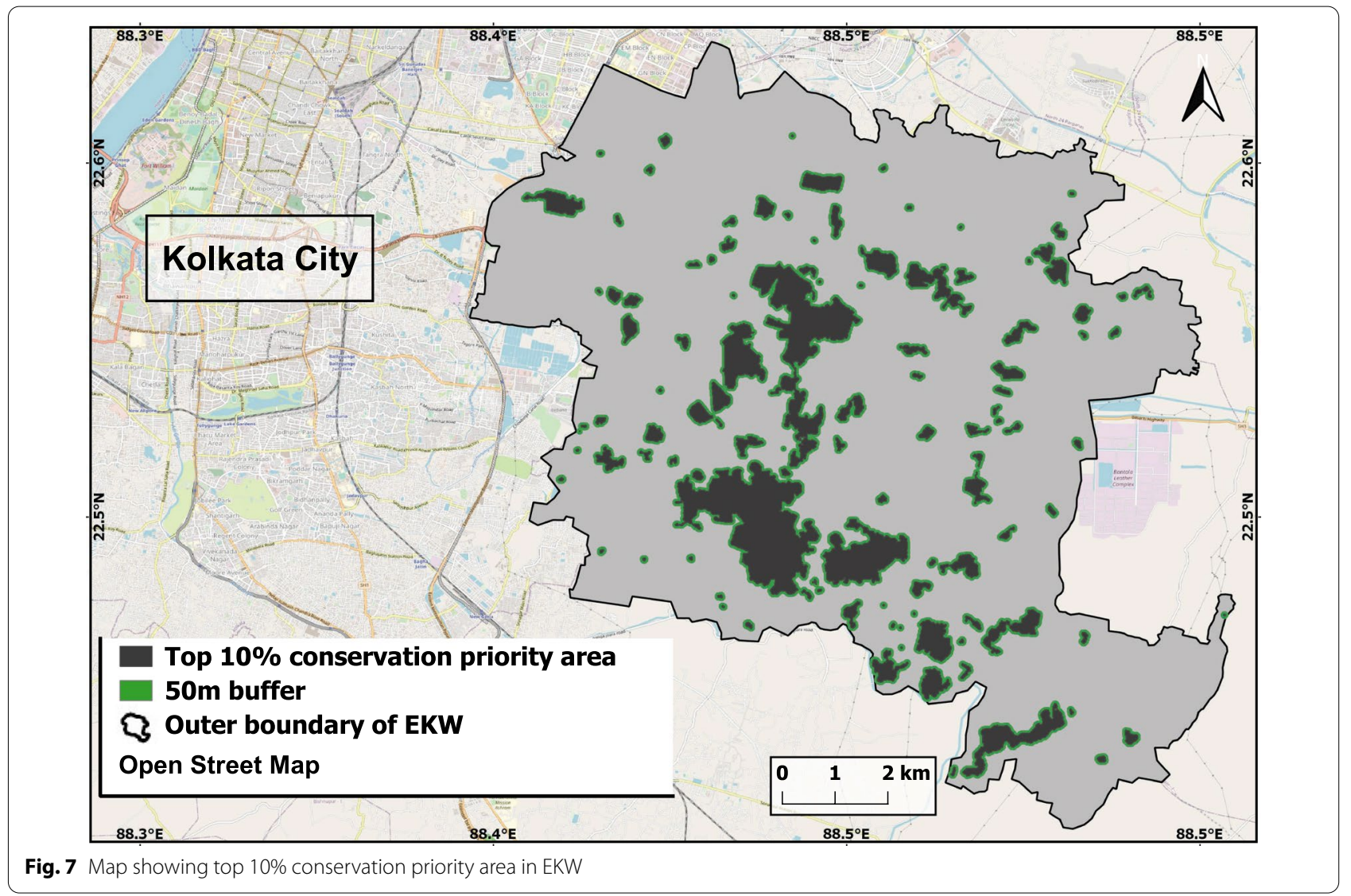

of paddy stands in the agricultural fields also provides necessary refuge and hiding places from their natural enemies and the narrow muddy borders between adjacent agricultural fields are often reported to be used by the birds for dispersal (King et al. 2010; Wilcoxen et al. 2018; Barik et al. 2021b). Mixed cropping patterns increase the spatiotemporal heterogeneity of agricultural fields in EKW, which are known to positively influence the avian communities (Thenail et al. 2009; Siriwardena et al. 2012; Sarkar and Parihar 2014). At landscape scale, we also found a positive influence of wetland area on avian diversity. Ducks and other piscivorous birds in the study area depend on open waters (Zhang et al. 2018). The shallow wetlands in parts of EKW (Barik et al. 2021b; EKWMA and WISA 2021) also provide foraging habitat for several water birds, particularly waders (Colwell and Taft 2000). Aquatic insects are abundant in waterbodies of EKW (Saha et al. 2017), which also influence avifauna (Ferger et al. 2014). We found that bird diversity was positively influenced by presence of dikes and banks at local scale (Table 4, Fig. 5). Presence of diverse plants provides refuge for several wetland-dependent birds (Barik et al. 2021b). On other hand, connectivity between resource patches is important for safe dispersal of individuals, thereby providing them with optimal foraging and mating conditions (St-Louis et al. 2014). Dikes in EKW provide such habitat connectivity for several species of birds (Barik et al. 2021b). Emergent vegetation patches are sparsely distributed in EKW and provide natural habitats for marsh dwelling birds (e.g., bitterns, birds species of family Rallidae, etc.), herons, munias (Family Estrildidae), shrikes, warblers and prinias (Grimmett et al. 2013; Rajpar and Zakaria 2011; Bradshaw et al. 2020). Emergent vegetations on dikes and banks often provide hiding places for several birds (Barik et al. 2021b). Therefore, it is an important land cover feature and positively influences the bird diversity at landscape level (Table 4, Fig. 5).

On the contrary, built-up areas adversely influenced the bird diversity at local scale (Table 4, Fig. 5). Expansion of human habitations often create disturbances. Usually the generalist species show high adaptability in such altered environments, while the specialist species are less adaptive to such disturbances (Sultana et al. 2021). Generally, rapid urban growth leads to 'biotic homogenization' (McKinney 2006) wherein only urban exploiters or 
Table 5 Areas $\left(\mathrm{km}^{2}\right)$ of land cover types falling under higher and lower than mean species diversity and top 10\% conservation priority areas in EKW

\begin{tabular}{lccc}
\hline Land cover & $\begin{array}{l}\text { Lower than mean species diversity } \\
(<\mathbf{2 . 2 6 2 )}\end{array}$ & $\begin{array}{l}\text { Higher than mean species diversity } \\
(>\mathbf{2 . 2 6 2})\end{array}$ & $\begin{array}{l}\text { Top 10\% } \\
\text { conservation } \\
\text { priority area }\end{array}$ \\
\hline Wetlands & 17.80 & 19.22 & 2.75 \\
Emergent vegetation & 6.92 & 11.01 & 2.75 \\
Agricultural field & 7.89 & 13.14 & 0.56 \\
Tree cover & 2.67 & 3.48 & 0.01 \\
Human-settlements & 10.25 & 13.83 & 2.75 \\
Barren lands & 0.90 & 0.93 & 0.23 \\
Dikes and banks & 4.96 & 7.58 & 2.75 \\
Fallow lands & 2.71 & 4.96 & 1.02 \\
Total & 54.09 & 74.15 & 12.82 \\
\hline
\end{tabular}

synurbic species (Palomino and Carrascal 2006) flourish by using the artificial and built-up structures as nesting sites and by foraging on abundant and predictable food refuse discarded by city dwellers (Shochat et al. 2010). This corroborates our hypothesis that the species diversity in EKW increased with increasing distance from the city boundary of Kolkata, as the dominance of urban exploiters increases, but the overall species richness declines near the city boundary as compared to the natural areas away from the city.

\section{Spatial conservation prioritization and management implications}

Rapid urbanization has already resulted in the decline in avian species richness reported earlier from some of the northwest areas of EKW (Bhattacharyya et al. 2008). In EKW, only 162 species have been noted during the last 30 years, among them several migratory bird species were infrequently detected (EKWMA and WISA 2021). Increasing road density is known to negatively influence various species of birds (Husby 2016). We also noticed that many areas with lower avian diversity in EKW (i.e. diversity index value $<$ mean species diversity index of the study area) are situated adjacent to the major roads Eastern Metropolitan Bypass road (EM bypass) and State Highway 6 (SH6) (Fig. 6). The rate of wetland transformation is also higher in the western portion of EKW (Ghosh et al. 2018), which includes areas adjacent to Kolkata city. So, the urban avoiders still thriving in the western part of EKW are under serious threats due to intense urbanization pressure. On the other hand, the wetland transformation rate is lower in the south-eastern portion of EKW and we found $11.43 \mathrm{~km}^{2}$ areas with higher than mean species diversity in this area.

It is evident from our findings that the association of land cover features with the avian assemblages varied at local and landscape scales, which conjointly shape the bird communities of an area. Hence, we need to consider both of them while framing conservation planning (Litteral and Shochat 2017). Furthermore, we have projected the top $10 \%$ conservation priority areas in EKW (Fig. 7), of which almost half is under wetland cover, emergent vegetation and agricultural field (Table 5). Alarmingly, fertilizers and pesticides are extensively used in those agricultural fields (Ghosh et al. 2018) thereby posing an imminent threat of the dearth of various resources there, particularly the availability of insects (Benton et al. 2002; Goulson 2014). Intensive and commercial sewage-fed pisciculture is practised in these water bodies of EKW, which leads to the bioaccumulation of harmful heavy metals in cultured fishes (Dutta and Chakraborty 2017). This poses a potential risk to the piscivores found in EKW. Emergent vegetation patches are vanishing due to urban encroachment, crop and fish farming activity. We also noticed that several birds died being entangled in fishnets (pers. obs.), and locals reported that a few species are captured for illegal pet trade. All these are emerging as serious threats to bird species in EKW, as well as many wetland habitats across the globe. Nevertheless, these potential risks need to be quantified in future studies.

\section{Conclusion}

We described the foraging guild structure of avifauna in EKW. Next, we prepared a spatial map of avian diversity in EKW, and identified high species diversity areas for bird conservation. Our study suggests that wetland management strategy needs to contemplate both local and landscape level characteristics to improve overall avifaunal diversity of EKW. Our findings clearly indicate that a mix of agricultural field, wetlands areas and emergent vegetation can support a high number of bird species in 
EKW. Besides, protection of important land use features and the remaining natural habitats, as well as, restoration of degraded habitats and reduction of anthropogenic threats (particularly in the north-eastern parts of EKW and areas adjacent to the city periphery, EM bypass and SH6), involving local communities might serve as a decisive factor for the conservation of the avian diversity in EKW. Birds serve as important surrogate of biodiversity, and are useful to prioritize areas for conservation of biodiversity across the globe. Therefore, prioritizing conservation initiatives in the top $10 \%$ areas projected during the present study will not only be cost effective (Moilanen et al. 2011) for the protection of birds, but also will be useful in conserving the overall biodiversity of these areas. Maintenance of shrubs and emergent vegetation along the dikes and banks of the wetlands (Barik et al. 2021b), prevention of the use of nets over commercial fish ponds and lowering the anthropogenic pressure in these high diversity areas are crucial. Such conservation initiatives need to be urgently implemented in those top $10 \%$ priority areas of this internationally acclaimed wetland engaging all stakeholders (landholders, fishermen, farmers etc.). Awareness campaigns among the local residents, particularly those residing in the projected conservation priority areas, might be useful in sustaining the avian diversity (Sterling et al. 2017) of EKW. Similar studies may be carried out in prioritizing the areas for conservation of avifauna in wetlands across the globe, particularly those situated at human-dominated landscapes.

\begin{abstract}
Abbreviations
EKW: East Kolkata Wetlands; KMC: Kolkata Municipal Corporation; HBW: Handbook of the birds of the wild; PAST: Paleontological statistics software; AHC: Agglomerative hierarchical cluster; UPGA: Unweighted pair-group average; GLM: Generalized linear model; VIF: Variance inflation factor; AICc: Secondorder Akaike's information criterion; PCA: Principal component analysis; PC: Principal components; WA: Water area; DB: Dikes and banks; AF: Agricultural field; TC: Tree cover; OG: Open ground; BA: Built-up area; DKMCB: Distance to KMC boundary.
\end{abstract}

\section{Supplementary Information}

The online version contains supplementary material available at https://doi. org/10.1186/s13717-022-00369-x.

Additional file 1. List of birds (order, family, common and scientific names, foraging guild structure and dispersal status) recorded from East Kolkata Wetlands, West Bengal, India.

\section{Acknowledgements}

We express our gratitude for the Head, Department of Zoology, University of Calcutta and the Principal, Shibpur Dinobundhoo Institution (College) for their encouragement and infrastructural support. We thank Mr. Souvik Chakraborty (Data analyst, IBM, Kolkata) for his statistical assistance. We also thank Editor-inChief Jiquan Chen, and two anonymous reviewers for their constructive input on earlier versions of this paper, which helped us to improve this article.

\section{Authors' contributions}

SM and GKS designed the study. SB carried out field surveys. SB and SM did the data analyses and wrote the draft manuscript. GKS helped to improve the manuscript. All authors read and approved the final manuscript.

\section{Funding}

The expenses during the research were borne by the authors and not funded by any external agency.

\section{Availability of data and materials}

All data produced from this study are provided in this manuscript.

\section{Declarations}

\section{Ethics approval and consent to participate}

This paper contains findings of our original research. Applicable national and/ or international guidelines for animal ethics were followed and no animal was harmed during the study. We adhered to the ethical standards in this study and in production of this manuscript.

\section{Consent for publication}

The article submitted herewith contains the findings of our original research, is not under consideration for publication elsewhere, and is approved by all authors of this manuscript.

\section{Competing interests}

The authors declare that they have no conflict of interest (financial or nonfinancial) in publishing the manuscript.

\section{Author details}

'Department of Zoology, University of Calcutta, 35, Ballygunge Circular Road, Kolkata 700019, India. ${ }^{2}$ Department of Zoology, Shibpur Dinobundhoo Institution (College), Shibpur, Howrah, India.

Received: 17 November 2021 Accepted: 7 February 2022

Published online: 07 March 2022

References

Abburu S, Golla SB (2015) Satellite image classification methods and techniques: a review. Int J Comput Appl 119(8):20-25

Abdi H, Williams LJ (2010) Principal components analysis. Wires Comp Stat 2:433-450

Alexandrino ER, Buechley ER, Piratelli AJ, de Barros KM, de Andrade MR, Sekercioğlu ÇH, Silva WR, do Couto HT (2016) Bird sensitivity to disturbance as an indicator of forest patch conditions: an issue in environmental assessments. Ecol Indic 66:369-381

Ali S, Ripley SD, Dick JH (1987) Compact handbook of the birds of India and Pakistan. Oxford University Press, Delhi

Anderson JR, Hardy EE, Roach JT, Witmer RE (1976) A land use and land cover classification system for use with remote sensor data. US Geological Survey Professional Paper 964. US Government Printing Office, USA

Barik S, Saha GK, Mazumdar S (2021a) How the habitat features influence Black-headed Ibis (Threskiornis melanocephalus) in a suburban area? A study from Mid-West Bengal India. Proc Zool Soc. https://doi.org/10. 1007/s12595-021-00385-3

Barik S, Saha GK, Mazumdar S (2021 b) Potentially suitable habitat, connectivity and priority conservation areas for White-breasted waterhen (Amaurornis phoenicurus) and Bronze-winged jacana (Metopidius indicus). Wetlands 41(3):1-15

Barik S, Saha GK, Mazumdar S (2021c) Environmental features influencing Redwattled Lapwing and River Lapwing in a suburban area of the lower Gangetic plains, West Bengal, India. Wader Study 128(3):247-254

Bennett AF, Haslem A, Cheal DC, Clarke MF, Jones RN, Koehn JD, Lake PS, Lumsden LF, Lunt ID, Mackey BG, Nally RM (2009) Ecological processes: a key element in strategies for nature conservation. Ecol Manag Restor 10(3):192-199 
Benton TG, Bryant DM, Cole L, Crick HQ (2002) Linking agricultural practice to insect and bird populations: a historical study over three decades. J Appl Ecol 39(4):673-687

Bhattacharyya A, Sen S, Roy PK, Mazumdar A (2008) A critical study on status of East Kolkata Wetlands with special emphasis on water birds as bioindicator. In: Sengupta M, Dalwani R (eds) Proc. of Taal 2007: The 12th World Lake Conference, India: Ministry of Environment and Forests, Govt of India, pp 1561-1570

Bibby CJ, Burgess ND, Hillis DM, Hill DA, Mustoe S (2000) Bird census techniques. Elsevier, Great Britain

Blair RB, Johnson EM (2008) Suburban habitats and their role for birds in the urban-rural habitat network: points of local invasion and extinction? Landsc Ecol 23(10):1157-1169

Bradshaw TM, Blake-Bradshaw AG, Fournier AM, Lancaster JD, O'Connell J, Jacques CN, Eichholz MW, Hagy HM (2020) Marsh bird occupancy of wetlands managed for waterfowl in the Midwestern USA. PLoS ONE 15(2):e0228980

Burin G, Kissling WD, Guimarães PR, Şekercioğlu ÇH, Quental TB (2016) Omnivory in birds is a macroevolutionary sink. Nat Commun 7(1):11250

Campbell JB (1996) Introduction to Remote Sensing, 2nd edn. Taylor and Francis, London

Cohen J (1960) A coefficient of agreement for nominal scales. Educ Psychol Meas 20(1):37-46

Colwell MA, Taft OW (2000) Waterbird communities in managed wetlands of varying water depth. Waterbirds 23(1):45-55

Congedo L (2014) Land cover classification of cropland: a tutorial using the semi-automatic classification plugin for QGIS. Sapienza University, Rome

Congedo L (2016) Semi-automatic classification plugin documentation. Release 6.0.1.1. 4(1):1-29 https://www.researchgate.net/publication/ 307593091_SemiAutomatic_Classification_Plugin_Documentation_ Release_6011. Accessed 06 Oct 2021

del Hoyo J, Collar NJ, Christie DA, Elliot A, Fishpool LDC (2014) Illustrated checklist of the birds of the world. Lynx Edicions, Barcelona

Di Minin E, Veach V, Lehtomäki J, Montesino Pouzols F, Moilanen A (2014) A quick introduction to Zonation. Helsingin Yliopisto, Helsinki

Douglas Robinson W, Hau M, Klasing KC, Wikelski M, Brawn JD, Austin SH, Tarwater CE, Ricklefs RE (2010) Diversification of life histories in New World birds. Auk 27(2):253-262

Dutta S, Chakraborty S (2017) The effect of pollution on hydrological parameters analysis of East Kolkata Wetland Area. Int J Dev Res 7(9):15452-15458

East Kolkata Wetlands Management Authority (EKWMA) (2010) EKW Management Plan. East Kolkata Wetlands Management Authority, India

EKWMA, WISA (2021) East Kolkata Wetlands: Management Action Plan 2021-2026. East Kolkata Wetlands Management Authority and Wetlands International South Asia. Kolkata, India

Ferger SW, Schleuning M, Hemp A, Howell KM, Böhning-Gaese K (2014) Food resources and vegetation structure mediate climatic effects on species richness of birds. Glob Ecol Biogeogr 23(5):541-549

Fox J, Monette G (1992) Generalized collinearity diagnostics. J Am Stat Assoc 87(417):178-183

Fox J, Weisberg S (2019) An R companion to applied regression, 3rd edn. Sage, Thousand Oaks

Fraser LH, Keddy PA (2005) The world's largest wetlands: ecology and conservation. Cambridge University Press, New York

Ghosh AK (1990) Biological resources of East Calcutta Wetlands. IJLS \& ES $13(1): 10-23$

Ghosh D, Sen S (1987) Ecological history of Calcutta's wetland conservation. Environ Conserv 14(3):219-226

Ghosh S, Dinda S, Chatterjee ND, Das K (2018) Analyzing risk factors for shrinkage and transformation of East Kolkata Wetland. India Spat Inf Res 26(6):661-677

Giosa E, Mammides C, Zotos S (2018) The importance of artificial wetlands for birds: a case study from Cyprus. PLoS ONE 13(5):e0197286

Goulson D (2014) Pesticides linked to bird declines. Nature 511(7509):295-296

Graham MH (2003) Confronting multicollinearity in ecological multiple regression. Ecology 84:2809-2815
Grimmett R, Inskipp C, Inskipp T (2013) Birds of the Indian subcontinent: India, Pakistan, Sri Lanka, Nepal, Bhutan, Bangladesh and the Maldives. Bloomsbury Publishing, New Delhi

Gutiérrez-Tapia P, Azócar MI, Castro SA (2018) A citizen-based platform reveals the distribution of functional groups inside a large city from the Southern Hemisphere: e-Bird and the urban birds of Santiago (Central Chile). Rev Chil Hist Nat 91(1):3

Gwelo AS (2019) Principal components to overcome multicollinearity problem. OJBE 4(1):79-91

Hammer $\varnothing$, Harper DA, Ryan PD (2001) Paleontological statistics software: package for education and data analysis. Palaeontol Electron 4(1):1-9

Hand book of the world alive (2021) Lynx Edicions. http://www.hbw.com/ Accessed 06 Oct 2021.

Harris CM, Calladine JR, Wernham CV, Park KJ (2008) Impacts of piscivorous birds on salmonid populations and game fisheries in Scotland: a review. Wildlife Biol 14(4):395-411

Hughes J, Beiner D, Hughes MJ (2021) Helper functions for regression analysis: package 'reghelper' version 1.1.0. https://cran.rproject.org/web/ packages/reghelper/reghelper.pdf. Accessed 11 Dec 2021

Husby M (2016) Factors affecting road mortality in birds. Ornis Fenn 93:212-224

Izaguirre MIR, Ramírez-Alán O (2018) Acoustic indices applied to biodiversity monitoring in a Costa Rica dry tropical forest. J Ecoacoust 2:5

Jolliffe IT (2002) Choosing a subset of principal components or variables. Principal component analysis, Springer series in statistics. Springer, New York, pp 111-149

Jude OC, Iheoma AT, Elizabeth AE, Eja El (2018) Spatial distribution of ecotourism resources in anambra state: a nearest neighbour analysis approach. Am Int J Soc Sci 6(3):29-38

Kaliyadan F, Kulkarni V (2019) Types of variables, descriptive statistics, and sample size. Indian Dermatol Online J 10(1):82-86

King S, Elphick CS, Guadagnin D, Taft O, Amano T (2010) Effects of landscape features on waterbird use of rice fields. Waterbirds 33:151-159

Koper N, Schmiegelow FK (2006) A multi-scaled analysis of avian response to habitat amount and fragmentation in the Canadian dry mixed grass prairie. Landsc Ecol 21:1045-1059

Krebs CJ (1989) Ecological methodology. Harper and Row Publishers, New York, p 654

Kurucz K, Purger JJ, Batáry P (2021) Urbanization shapes bird communities and nest survival, but not their food quantity. Glob Ecol Conserv 26:e01475

La Sorte FA, Lepczyk CA, Aronson MF, Goddard MA, Hedblom M, Katti M, MacGregor-Fors I, Mörtberg U, Nilon CH, Warren PS, Williams NS (2018) The phylogenetic and functional diversity of regional breeding bird assemblages is reduced and constricted through urbanization. Divers Distrib 24(7):928-938

Lamy T, Liss KN, Gonzalez A, Bennett EM (2016) Landscape structure affects the provision of multiple ecosystem services. Environ Res Lett 11(12):124017

Landis JR, Koch GG (1977) An application of hierarchical kappa-type statistics in the assessment of majority agreement among multiple observers. Biometrics 1:363-374

Lee MB, Carroll JP (2014) Relative importance of local and landscape variables on site occupancy by avian species in a pine forest, urban, and agriculture matrix. Forest Ecol Manag 320:161-170

Lehtomäki J, Moilanen A (2013) Methods and workflow for spatial conservation prioritization using Zonation. Environ Model Softw 47:128-137

Leibowitz SG (2003) Isolated wetlands and their functions: an ecological perspective. Wetlands 23:517-531

Li J, Heap AD (2011) A review of comparative studies of spatial interpolation methods in environmental sciences: performance and impact factors. Ecol Inform 6(3-4):228-241

Litteral J, Shochat E (2017) The role of landscape-scale factors in shaping urban bird communities. In: Murgui E, Hedblom M (eds) Ecology and conservation of birds in urban environments. Springer, Cham, pp 135-159

Ludecke D, Makowski D, Waggoner P (2019) Performance: assessment of regression models performance. $R$ package (ver. 4.2). https://CRAN.Rproject.org/package=performance. Accessed 11 Dec 2021.

Manly BF (1994) Multivariate statistical methods: a primer. CRC Press, Boca Raton, p 215 
Mazerolle MJ (2020) Model selection and multimodel inference using the AlCcmodavg package. https://mirror.marwan.ma/cran/web/packages/ AlCcmodavg/vignettes/AICcmodavg.pdf. Accessed 11 Dec 2021

Mazumdar S, Saha GK (2016) Wetlands in urban landscapes: problems and potentials. In: Saha GK (ed) Wetland: crisis and options. Astral International Pvt. Ltd., New Delhi, pp 385-400

McElfish JM, Kihslinger RL, Nichols S (2008) Setting buffer sizes for wetlands. Natl Wetlands NewsI 30(2):6-17

McGarigal K (2015) FRAGSTATS help. University of Massachusetts, Amherst

McKinney ML (2006) Urbanization as a major cause of biotic homogenization. Biol Conserv 127(3):247-260

Millennium Ecosystem Assessment (MEA) (2005) Ecosystems and Human Wellbeing: Synthesis. Island Press, Washington DC

Moilanen A, Anderson BJ, Eigenbrod F, Heinemeyer A, Roy DB, Gillings S, Armsworth PR, Gaston KJ, Thomas CD (2011) Balancing alternative land uses in conservation prioritization. Ecol Appl 21(5):1419-1426

Morelli F, Benedetti Y, Šímová P (2018) Landscape metrics as indicators of avian diversity and community measures. Ecol Indic 90:132-141

Mukherjee J, Chakraborty G (2016) Commons vs commodity: Urban environmentalisms and the transforming tale of the East Kolkata Wetlands. Urbanities 6(2):78-91

O'Neil LJ, Carey AB (1986) Introduction: When habitats fail as predictors. In: Verner J, Morrison ML, Ralph CJ (eds) Wildlife 2000: Modeling habitat relationships of terrestrial vertebrates. University of Wisconsin Press, Madison, pp 207-208

Ouabo RE, Sangodoyin AY, Ogundiran MB (2020) Assessment of ordinary Kriging and inverse distance weighting methods for modeling chromium and cadmium soil pollution in E-waste sites in Douala, Cameroon. J Health Pollut 10(26):200605

Palomino D, Carrascal LM (2006) Urban influence on birds at a regional scale. A case study with the avifauna of northern Madrid province. Landsc Urban Plan 77:276-290

Parihar SM, Sarkar S, Dutta A, Sharma S, Dutta T (2013) Characterizing wetland dynamics: a post-classification change detection analysis of the East Kolkata Wetlands using open source satellite data. Geocarto Int 28(3):273-287

Pasher J, Mitchell SW, King DJ, Fahrig L, Smith AC, Lindsay KE (2013) Optimizing landscape selection for estimating relative effects of landscape variables on ecological responses. Landsc Ecol 28(3):371-383

Rajpar MN, Zakaria M (2011) Bird species abundance and their correlationship with microclimate and habitat variables at Natural Wetland Reserve, Peninsular Malaysia. Int J Zool 2011:758573. https://doi.org/10.1155/ 2011/758573

Ramsar Convention (2002) Information Sheet on Ramsar Wetlands. https://rsis. ramsar.org/RISapp/files/RISrep/IN1208RIS.pdf. Accessed 06 Oct 2021

Ripley B (2011) MASS: support functions and datasets for Venables and Ripley's MASS. R Package Version 7:3-29

Saha S, Basu P, Saha T (2014) Size does matter: role of large size wetlands in the diversity of wetland-dependent bird species of East Kolkata Wetlands. In: Das C (ed) Current perspectives in natural resource management. Progressive Publisher, Kolkata, pp 49-67

Saha S, Saha T, Basu P (2017) Seasonal changes in zooplankton and macrofauna populations of the East Calcutta Wetland fish ponds. Proc Zool Soc 70:156-164

Sarkar S, Parihar SM (2014) Mapping of cropping pattern of East Kolkata Wetland Area using multi-temporal satellite data. J Geomat 8(1):90-95

Shannon CE, Weaver W (1949) The mathematical theory of communication. University of Illinois Press, Urbana

Shochat E, Lerman S, Fernández-Juricic E (2010) Birds in urban ecosystems: population dynamics, community structure, biodiversity, and conservation. In: Aitkenhead-Peterson J, Volder A (eds) Urban ecosystem ecology Agronomy Monograph. Willey, USA, pp 75-86

Sica YV, Quintana RD, Bernardos JN, Calamari NC, Gavier-Pizarro Gl (2020) Wetland bird response to habitat composition and configuration at multiple spatial scales. Wetlands 40(6):2513-2525

Silva CP, García CE, Estay SA, Barbosa O (2015) Bird richness and abundance in response to urban form in a latin american city: Valdivia, Chile as a case study. PLoS ONE 10(9):e0138120. https://doi.org/10.1371/journal.pone. 0138120

Siriwardena GM, Cooke IR, Sutherland WJ (2012) Landscape, cropping and field boundary influences on bird abundance. Ecography 35(2):162-173
Smith C, Warren M (2019) GLMs in R for ecology. Amazon Publishing, Seattle Snep RPH, Kooijmans JL, Kwak RGM, Foppen RPB, Parsons H, Awasthy M, Sierdsema HLK, Marzluff JM, Fernandez-Juricic E, de Laet J, van Heezik YM (2015) Urban bird conservation: presenting stakeholder-specific arguments for the development of bird-friendly cities. Urban Ecosyst 19(4):1535-1550

Sohil A, Sharma N (2020) Assessing the bird guild patterns in heterogeneous land use types around Jammu, Jammu and Kashmir, India. Ecol Process 9:49

Sterling EJ, Betley E, Sigouin A, Gomez A, Toomey A, Cullman G, Malone C, Pekor A, Arengo F, Blair M, Filardi C (2017) Assessing the evidence for stakeholder engagement in biodiversity conservation. Biol Conserv 209:159-171

St-Louis V, Forester JD, Pelletier D, Bélisle M, Desrochers A, Rayfield B, Wulder MA, Cardille JA (2014) Circuit theory emphasizes the importance of edge-crossing decisions in dispersal-scale movements of a forest passerine. Landsc Ecol 29(5):831-841

Sultana M, Corlatti L, Storch I (2021) The interaction of imperviousness and habitat heterogeneity drives bird richness patterns in south Asian cities. Urban Ecosyst 24(2):335-344

Sundar KG, Kittur S (2013) Can wetlands maintained for human use also help conserve biodiversity? Landscape-scale patterns of bird use of wetlands in an agricultural landscape in north India. Biol Conserv 168:49-56

Thenail C, Joannon A, Capitaine M, Souchère V, Mignolet C, Schermann N, Di Pietro F, Pons Y, Gaucherel C, Viaud V, Baudry J (2009) The contribution of crop-rotation organization in farms to crop-mosaic patterning at local landscape scales. Agric Ecosyst Environ 131(3-4):207-219

Touhami F, Bazairi H, Badaoui B, Morabbi A, Benhoussa A (2019) Structure and spatial organization of macrobenthic fauna of intertidal habitats frequented by wintering shorebirds at Merja Zerga lagoon Moroccan Ramsar Site. Cah Biol Mar 60(1):41-50

van Steenderen C (2020) BinMat: a molecular genetics tool for processing binary data obtained from fragment analysis in R. Authorea Preprints. https://CRAN.R-project.org/package=BinMat. Accessed 06 Oct 2021

Wilcoxen CA, Walk JW, Ward MP (2018) Use of cover crop fields by migratory and resident birds. Agric Ecosyst Environ 252:42-50

Zhang Y, Fox AD, Cao L, Jia Q, Lu C, Prins HH, de Boer WF (2018) Effects of ecological and anthropogenic factors on waterbird abundance at a Ramsar Site in the Yangtze River Floodplain. Ambio 48:293-303

Zuur A, leno EN, Smith GM (2007) Analyzing ecological data. Springer, New York

Zuur AF, leno EZ, Walker NJ, Saveliev AA, Smith GM (2009) GLM and GAM for count data. In: Zuur AF, leno EN, Walker N, Saveliev AA, Smith GM (eds) Mixed effects models and extensions in ecology with R Statistics for Biology and Health. Springer, New York, pp 209-243

\section{Publisher's Note}

Springer Nature remains neutral with regard to jurisdictional claims in published maps and institutional affiliations.

\section{Submit your manuscript to a SpringerOpen ${ }^{\circ}$ journal and benefit from:}

- Convenient online submission

- Rigorous peer review

- Open access: articles freely available online

- High visibility within the field

- Retaining the copyright to your article

Submit your next manuscript at springeropen.com 